\title{
Erratum to: Toward establishing a morphological and ultrastructural characterization of proembryogenic masses and early somatic embryos of Araucaria angustifolia (Bert.) 0 . Kuntze
}

\author{
Neusa Steiner ${ }^{1}$ - Francine L. Farias-Soares ${ }^{2}$ Éder C. Schmidt ${ }^{3}$ Maria L. T. Pereira ${ }^{4}$. \\ Bruna Scheid $^{4}$ • Gladys D. Rogge-Renner ${ }^{3,7}$ • Zenilda L. Bouzon ${ }^{3,5}$ • Daniela Schmitz ${ }^{4}$. \\ Sara Maldonado ${ }^{6}$. Miguel P. Guerra ${ }^{4}$
}

Published online: 30 January 2017

(C) Springer-Verlag Wien 2017

Erratum to: Protoplasma (2016) 253:487-501

DOI 10.1007/s00709-015-0827-0

The published online version of the paper contains mistake on one author name. Daniela Schmidt should be Daniela Schmitz. The corrected name is shown in the author group section above.

The online version of the original article can be found at http://dx.doi. org/10.1007/s00709-015-0827-0

Neusa Steiner

neusa.steiner@ufsc.br

Plant Physiology Laboratory, Department of Botany, Federal University of Santa Catarina, Florianópolis, SC 88040-900, Brazil

2 Graduate Program in Plant Genetic Resources, Department of Plant Science, Federal University of Santa Catarina, C.P. 476, Florianópolis, SC 88040-900, Brazil

3 Plant Cell Biology Laboratory, Department of Cell Biology, Embryology and Genetics, Federal University of Santa Catarina, C.P. 476, Florianópolis, SC 88049-900, Brazil
4 Laboratory of Plant Developmental Physiology and Genetics, Department of Plant Science, Federal University of Santa Catarina, C.P. 476, Florianópolis, SC 88040-900, Brazil

5 Central Laboratory of Electron Microscopy, Federal University of Santa Catarina, Florianópolis, SC, Brazil

6 Departamento de Biodiversidad y Biología Experimental, Facultad de Ciencias Exactas y Naturales, Universidad de Buenos Aires, Intendente Guiraldes 2160, Pab. 2, Ciudad Universitaria, C1428EGA Buenos Aires, Argentina

Department of Biological Sciences, University of Joinville Region, Joinville, SC, Brazil 